\title{
The effect of rainfall, soil type and slope on the processes and mechanism of rainfall-induced landslide
}

\author{
Yan Liu, Zhiyuan Deng and Xiekang Wang*
}

\author{
State Key Laboratory of Hydraulics and Mountain River Engineering, Sichuan University, Chengdu 610065, \\ China; liuyan2021scu@gmail.com (Y.L.); dengzhiyuan2019@163.com (Z.D.) \\ * Correspondence: wangxiekang@scu.edu.cn
}

\begin{abstract}
Landslides are serious geological hazards that become a disaster worldwide, causing a large number of casualties and economic losses every year. There are many factors affecting landslide susceptibility, such as rainfall, soil and slope. Each of them has an important role in the process of slope losing stability. In this paper, the effects of rainfall intensity, rainfall pattern, slope gradient and soil type on landslide susceptibility are studied. In the process of rainfall-induced landslide, the relevant physical quantities of soil changes continuously. Their values and processes are closely related to the time of landslide occurrence. Hence, the variation of soil volumetric water content, matrix suction, pore water pressure and total stress throughout the rainfall are measured. As the results, soil type, slope gradient and rainfall intensity have a large influence on landslide susceptibility. The occurrence of landslides has a prerequisite that the slope is greater than or equal to $15^{\circ}$. The rainfall intensity needs to be not less than $80 \mathrm{~mm} / \mathrm{h}$. The difference of rainfall pattern also affects the landslide susceptibility. The rainfall pattern with rainfall intensity peak at the later stage is more likely to induce landslide. Coarser soils with gravels are prone to landslides when other conditions are the same. Steeper slopes, stronger rainfall, and coarser soils can all increase the amount of sediment yield.
\end{abstract}

Keywords: landslides; artificial rainfall; grain size; rainfall pattern; pore water pressure

\section{Introduction}

Landslide refers to the geological phenomenon of rock and soil mass sliding along the through shear failure surface on the slope, which is a type of natural hazard that is widely distributed throughout the world [1,2]. Landslide disasters cause tens of billions of dollars of economic losses and serious casualties worldwide every year. [3]. In areas with complex geological conditions, landslides occur more frequently [4-7].

In mountain regions, landslides are often triggered by intensive rainfall [8,9]. The rainfall will enhance moisture content, which further decreases the matrix suction and soil shear strength, causing landslides [10,11]. To date, there have been many studies on the effects of rainfall on landslides. The research methods include in situ experiments, laboratory experiments and numerical simulations $[12,13]$. The artificial rainfall test is an effective method to study rainfall-induced landslides [14].

Slopes with different soil compositions respond differently to rainfall. Slopes composed of coarse grains and slopes composed of fine grains have different landslide susceptibility. The fine particle migration will lead to pore blockage [15]. The failure mode are closely related to the grain size [16]. The soil composition of slopes is closely related to landslide susceptibility. The prerequisite of landslides is that the clay percentage of the soil is higher than $2.5 \%$ [17]. Gravel soils are common in region where earthquake has happened. The proportion of gravel in soils has a great influence on density and void ratio, which dominates the time and type of landslides [18]. The type of landslides is usually a gully failure with small gravel content and usually manifested as a "layer-by-layer sliding" failure with large gravel content [19]. 
To investigate the physical changes of soil during the landslide, a lot of monitoring equipment has been used [20]. The infiltration will change the soil characteristics largely, such as the water content, matrix suction, pore water press and total stress [21,22]. Matrix suction is an sensitive parameter when the unsaturated soils dilate or contract [23]. The pore water press will increase with the increasing of slope gradient [24].

Landslide is one of the typical gravity erosion. The sediment yield of landslide varies with factors $[25,26]$. The time scale of the impact of landslide on sediment yield in the basin is large. In order to comprehensively analyze sediment transport, it is necessary to investigate the landslide history of the basin for at least 100 years [27]. The landslide sediment yield of the soil affected by the earthquake under the rainfall has been studied and quantified [28]. One model to express the contribution of shallow landslide to sediment yield as rainfall characteristic function have been established [29]. Another model called SHEETRAN is established to analyze the impact of rainfall on landslide and sediment transport. It is applied to the Luefregat River Basin [30-32]. The effects of rainfall on sediment yield is obvious [33]. The percentage of gravel affected sediment yield greatly. The sediment yield ascend with the increasing of gravel percentage [34].

\section{Materials and Methods}

\subsection{Experimental system}

The artificial rainfall test site is located in the State Key Laboratory of Hydraulics and Mountain River Engineering of Sichuan University. The system is composed of reservoir, water pump, water delivery pipe, rain gauge, electromagnetic flowmeter, nozzle and valve (Figure 1). It is controlled by computer software and can be self-adjusted automatically. When the automatic adjustment mode turned on, the water pressure and valve opening can be adjusted automatically to hold or change the rainfall intensity. Water content sensor, tensiometer, earth press cell, pore water pressure sensor and were used in the test (Figure 2(c)). The flume for test is made of impermeable transparent polymer plastic material, with a length of $2 \mathrm{~m}$, a width of $0.3 \mathrm{~m}$ and a height of $0.8 \mathrm{~m}$. The flume is placed horizontally. The three slope angles set in this research are $5^{\circ}, 15^{\circ}$ and $30^{\circ}$. The flume, soil and instrument are shown in Figure 2.

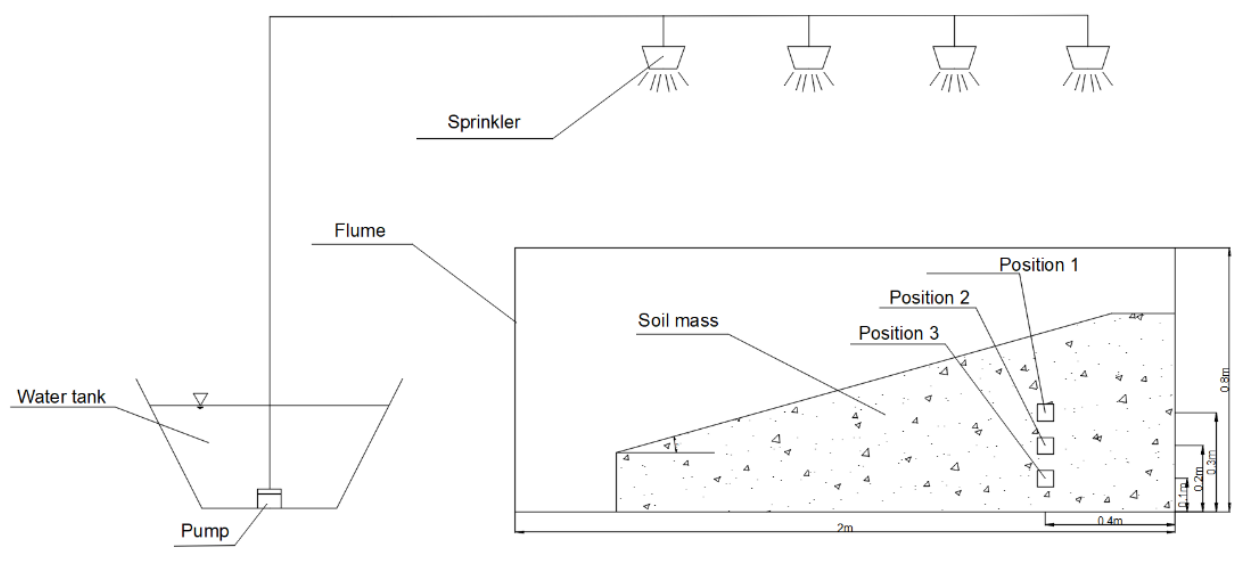

Figure 1. Sketch of experimental setup. 


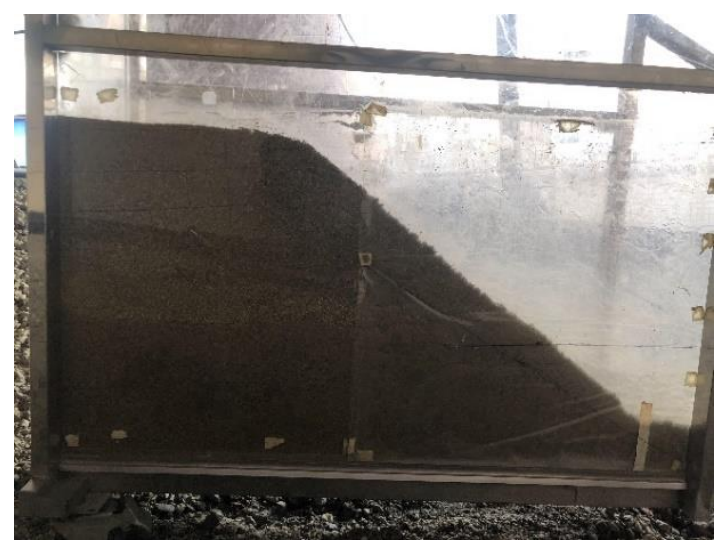

(a)

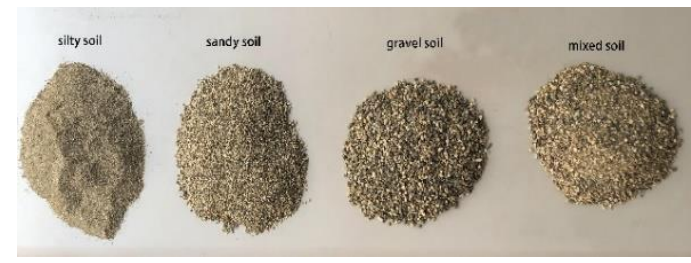

(b)

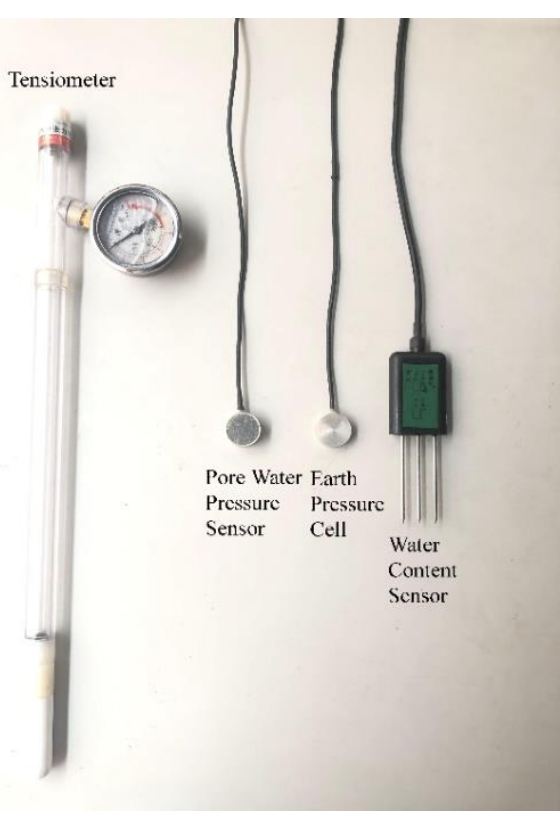

(c)

Figure 2. Tested samples and experimental apparatus: (a) Side view of the slope; (b) Soil samples; (c) Measuring apparatus.

\subsection{Experimental program}

The experiment was set up with four variables: rainfall intensity, rain pattern, soil type, and slope gradient (Table 1). A variable changed when other variables were controlled to be the same in order to study the relationship between that variable and landslide susceptibility. Four values of $40 \mathrm{~mm} / \mathrm{h}, 80 \mathrm{~mm} / \mathrm{h}, 120 \mathrm{~mm} / \mathrm{h}$ and $160 \mathrm{~mm} / \mathrm{h}$ were taken for the rainfall intensity variable when the rainfall pattern is uniform (Test no1-4). The rainfall pattern variable is set to I, II, III and IV (Test no 5-7 and 3), and their rainfall intensity change process is shown in Figure 3.

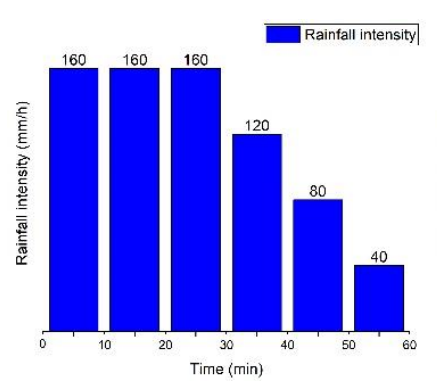

(a)

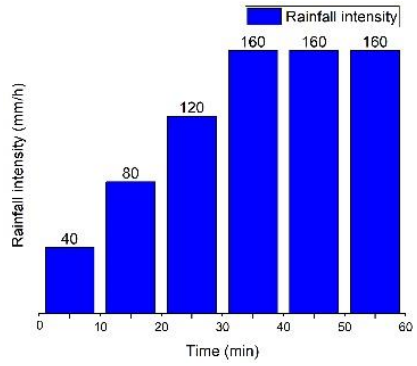

(b)

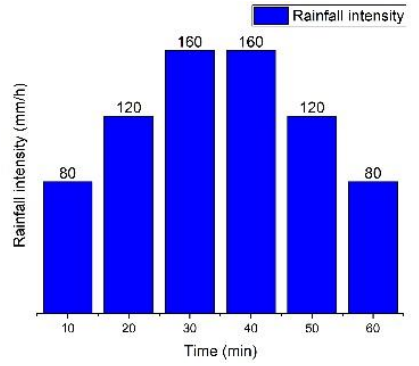

(c)

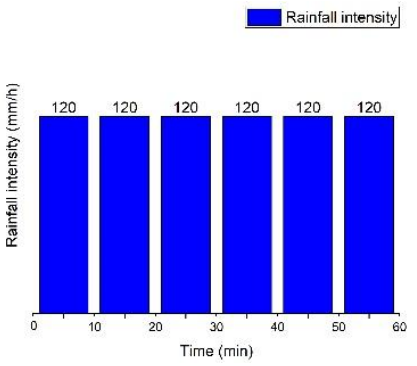

(d)

Figure 3. Rainfall Patterns: (a)Pattern I; (b) Pattern II; (c) Pattern III; (d) Pattern IV.

Table 1. Test Variables.

\begin{tabular}{ccclc}
\hline Test No. & $\begin{array}{c}\text { Rainfall } \\
\text { intensity } \\
(\mathbf{m m} / \mathbf{h})\end{array}$ & $\begin{array}{c}\text { Rainfall } \\
\text { pattern }\end{array}$ & Soil type & $\begin{array}{c}\text { Slope } \\
\text { gradient }\left(^{\circ} \text { ) }\right.\end{array}$ \\
\hline 1 & 40 & IV & Mixed soil & 15 \\
2 & 80 & IV & Mixed soil & 15 \\
3 & 120 & IV & Mixed soil & 15 \\
4 & 160 & IV & Mixed soil & 15 \\
5 & 120 & I & Mixed soil & 15
\end{tabular}




\begin{tabular}{ccccc}
6 & 120 & II & Mixed soil & 15 \\
7 & 120 & III & Mixed soil & 15 \\
8 & 120 & IV & Silty soil & 15 \\
9 & 120 & IV & Sandy soil & 15 \\
10 & 120 & IV & Gravel soil & 15 \\
11 & 120 & IV & Mixed soil & 5 \\
12 & 120 & IV & Mixed soil & 30 \\
\hline
\end{tabular}

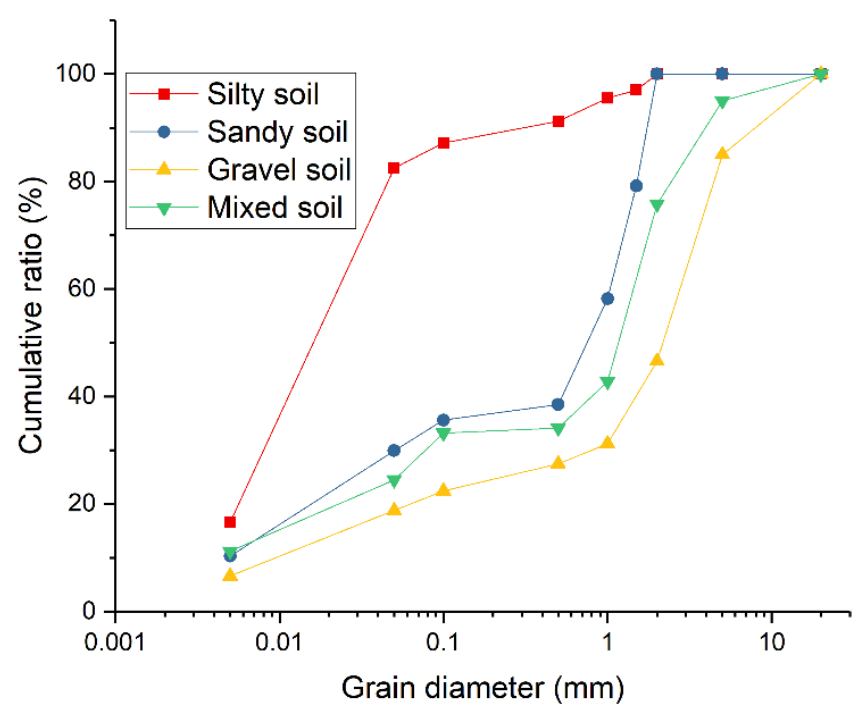

Figure 4. Grain-size distribution curves.

Four soil types were used for the test based on the common soil composition in nature (Test no 8-10 and 3). Three soil types are mainly composed of silt, sand and gravel, respectively, and the mixed type is a 1:1:1 mixture of the former three. The soil composition is listed in Table 2 and the grain size distribution curves of soil types are shown in Figure 4.

Table 2. Soil Composition.

\begin{tabular}{cccccccc}
\hline Soil type & $\begin{array}{c}\text { Clay } \\
\mathbf{( \% )}\end{array}$ & $\begin{array}{c}\text { Silt } \\
\mathbf{( \% )}\end{array}$ & $\begin{array}{c}\text { Sand } \\
\mathbf{( \% )}\end{array}$ & $\begin{array}{c}\text { Gravel } \\
\mathbf{( \% )}\end{array}$ & $\begin{array}{c}\text { D50 } \\
(\mathbf{m m})\end{array}$ & $\begin{array}{c}\text { Initial volume } \\
\text { moisture content } \\
\mathbf{( \% )}\end{array}$ & $\begin{array}{c}\text { Initial } \\
\text { dry density } \\
\left(\mathbf{g} / \mathbf{c m}^{\mathbf{3}}\right)\end{array}$ \\
\hline Silty soil & 10.2 & 68.6 & 21.2 & 0 & 0.021 & 9.1 & 1.88 \\
Sandy soil & 7.1 & 18.5 & 74.4 & 0 & 0.71 & 8.2 & 1.74 \\
Gravel soil & 8.8 & 16.9 & 18.6 & 55.7 & 2.54 & 6.5 & 1.50 \\
Mixed soil & 10.2 & 24.9 & 36.7 & 28.2 & 1.68 & 7.7 & 1.61 \\
\hline
\end{tabular}

\subsection{Test procedures}

Before a test begins, the soil was filled into the flume with each layer of $10 \mathrm{~cm}$. The soil was paved to the same thickness in each layer, and then knock it evenly with wood blocks. Measuring instruments were embedded in the positions shown in Figure 1. After the preparation were done, the test started with the rainfall. Each rainfall last 1 hour. At the end of a test, the amount of sediment yield by the landslide was measured.

\section{Results}

\subsection{Slope instability processes under different rainfall intensity}

When a slope encounters rainfall with different intensity, its water content, matrix suction, pore water pressure and total stress all exhibit different change processes. Water content is a basic parameter to describe the soil properties. The volumetric water content of the tests with higher rainfall intensity will rise earlier and the matrix suction will decline 
earlier too. When the rainfall intensity is $160 \mathrm{~mm} / \mathrm{h}$, the volumetric water content reaches its maximum at about $40 \mathrm{~min}$. When the rainfall intensity is $120 \mathrm{~mm} / \mathrm{h}$, the volumetric water content reaches its maximum at about $55 \mathrm{~min}$. The water penetrate gradually downward from the surface of the soil, so the volumetric water content in deep will increase later than the position near the surface.

Matrix suction is an important parameter of the mechanical properties of unsaturated soils. The pores of unsaturated soil are filled with water and air. The water-air interface has surface tension. In unsaturated soil by capillary action, the pore water pressure under the bent liquid surface is less than the pore air pressure. The shrinkage membrane is subjected to air pressure greater than the water pressure, and this pressure difference is called matrix suction. The process of matrix suction at different depths under different rainfall intensities is shown in Figure 5(b). It can be seen from the figure that the change curve of matrix suction is in three stages, namely, initial stage, steep fall stage and stable stage. Take the matrix suction change process at position I when the rainfall intensity is $160 \mathrm{~mm} / \mathrm{h}$ as an example. Within $22 \mathrm{~min}$ of the beginning of rainfall, the change of soil matrix suction is not obvious. 22-42 min, the matrix suction of the slope soil decreases abruptly. As the infiltration of rainfall continues to increase, the soil matrix suction decreases to the minimum and becomes stable.

Pore water pressure is the pressure of groundwater in soil or rock, which acts between particles or pores and is an important indicator of stress changes in the soil. The variation of pore water pressure at different locations of the slope under different rainfall intensities is shown in Figure 5(c). The pore water pressure variation curves during the test were in three stages: initial stage, surging stage and slow increasing stage. Specifically, the greater the intensity of rainfall, the shorter the duration of the initial stage. For example, the initial stage of pore water pressure at the Position I lasts about 8 min when the rainfall intensity is $160 \mathrm{~mm} / \mathrm{h}$, and about $24 \mathrm{~min}$ when the rainfall intensity is $40 \mathrm{~mm} / \mathrm{h}$.

The total stress is the total force per unit area acting within a mass of soil. It increase with the depth of the measurement point. Different rainfall intensities lead to different variation process of total stress. When the rainfall intensity is small, the total stress starts to increase a short time after rainfall begins and the increase process is relatively smooth. When the rainfall intensity is higher, the total stress starts to increase at the beginning of the rainfall.

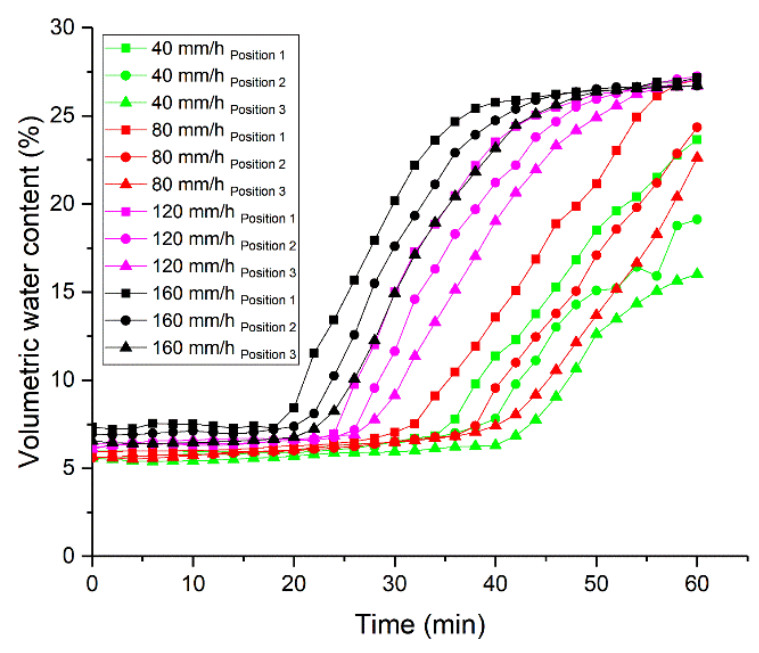

(a)

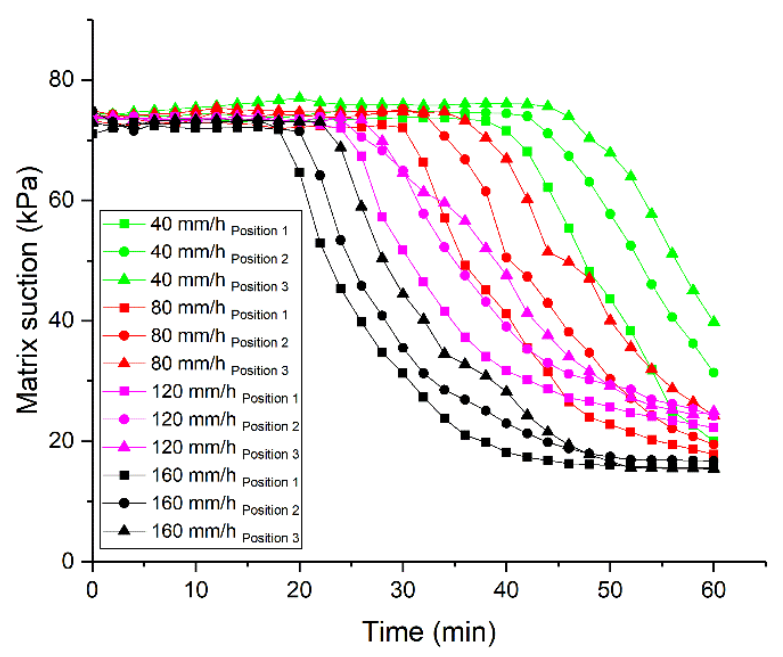

(b) 


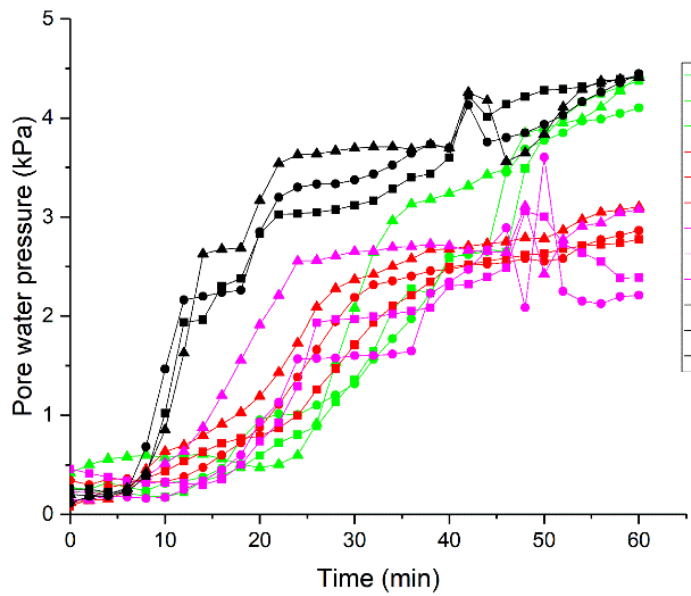

(c)

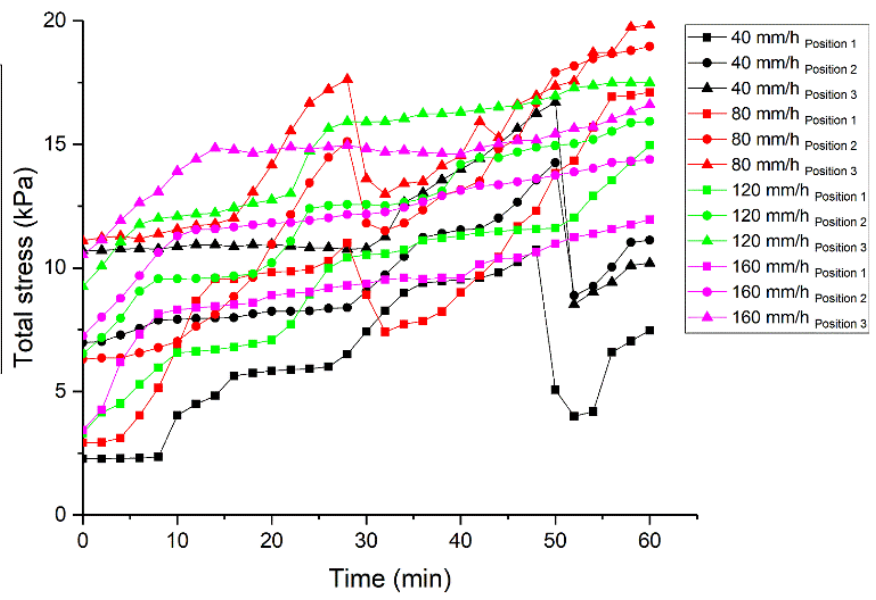

(d)

Figure 5. Variation in measured data when rainfall intensity is different: (a) Water content; (b) Matrix suction; (c) Pore water pressure; (d) Total stress.

The intensity of rainfall is closely related to the occurrence of landslide. When the intensity of rainfall is $40 \mathrm{~mm} / \mathrm{h}$ and $80 \mathrm{~mm} / \mathrm{h}$, no landslide occurs. For the case of rainfall intensity of $120 \mathrm{~mm} / \mathrm{h}$, the time of initial landslide occurrence is about $47 \mathrm{~min}$. For the case of rainfall intensity of $160 \mathrm{~mm} / \mathrm{h}$, the time of initial landslide occurrence is about $40 \mathrm{~min}$.

\subsection{Slope instability processes under different rainfall pattern}

The change of water content, matrix suction, pore water pressure and total stress under different rainfall pattern is shown in Figure 6. The volumetric water content measured at the measurement points did not change for a period of time after the onset of rainfall. The volumetric water content of the rainfall pattern I started to increase at the earliest. Later, the volumetric water content of the rainfall pattern IV and III started to increase. The volumetric water content of the rainfall pattern II started to increase last. The rate of increase of volumetric water content in the rain pattern I test decreased gradually. The rate of increase for the rainfall pattern IV test remained constant. The rate of increase for rain pattern II and rain pattern III gradually increased.

The matrix suction of the test with rainfall pattern I and rainfall pattern IV began to diminish earlier than that of pattern II and pattern III. The matrix suction curve of the test with rainfall pattern I and rainfall pattern IV begin to enter the attenuation stage at about $20 \mathrm{~min}$, while those of pattern II and pattern III begin to enter the attenuation stage at about $35 \mathrm{~min}$. The rainfall of pattern I and IV is relatively large in the initial stage. The attenuation processes are similar. In the stable stage, the matrix suction of test with pattern I and IV is the smallest, and those of pattern II and III is relatively large.

In the changing process of pore water pressure, the slow-changing stages of rain pattern I and IV tests lasted the shortest time. The rate of the curve is very large at the beginning. After the surge stage, it tends to be smooth. The slow change phase of rain pattern II and III lasted longer, and the pore water pressure increased slowly but throughout the test process. As the rainfall continues, the rainfall intensity of rain pattern II and III gradually increases, and the pore water pressure changes into the surge stage. The pore water pressure of rain pattern I, III and IV increased slightly in the stable stage.

Different rain patterns will cause different response processes of total stress. The soil response under rainfall pattern $\mathrm{I}$ is rapid. The total stress began to rise at $5 \mathrm{~min}$. The growth rate slows down at about $20 \mathrm{~min}$. The total stress of tests with rainfall pattern II and rain pattern III began to increase when it was close to $20 \mathrm{~min}$. Compared with rain pattern I, it lags behind. The total stress of tests with rainfall pattern II and rain pattern IV suddenly decreases in the later stage of rainfall because of the landslide. 


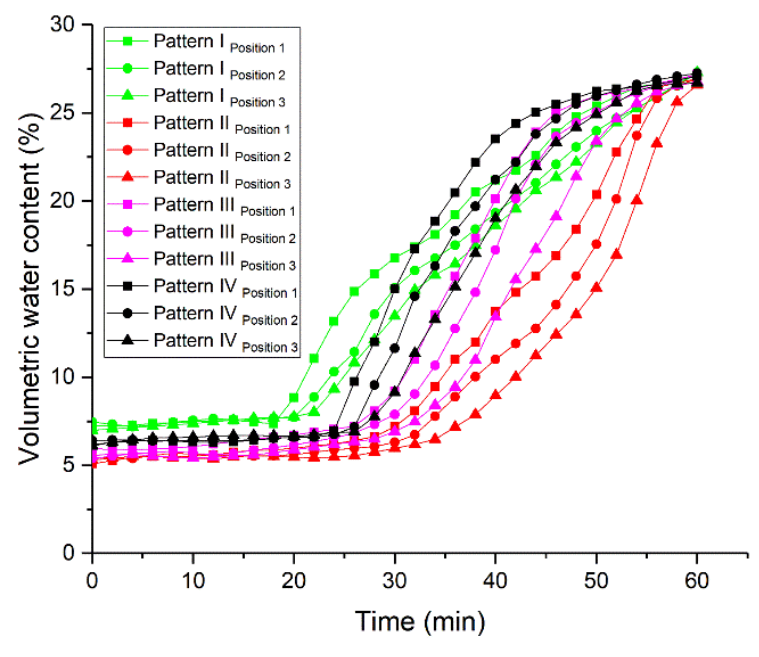

(a)

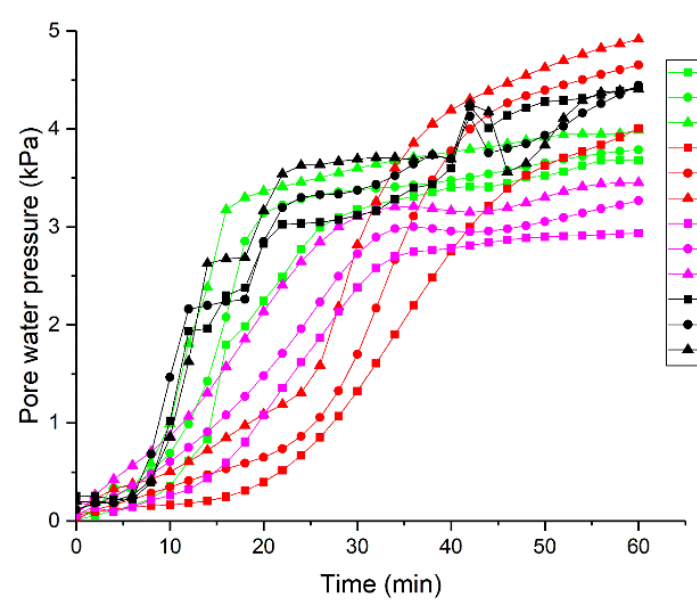

(c)

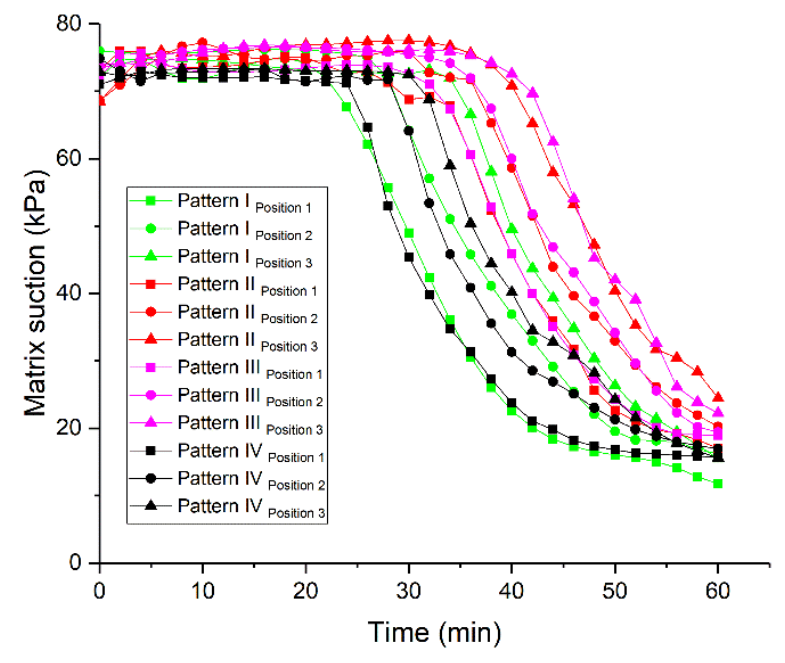

(b)

Figure 6. Variation in measured data when rainfall patterns are different: (a) Water content; (b) Matrix suction; (c) Pore water pressure; (d) Total stress.

The occurrence of landslides varies under different rain patterns: no landslides occur in Rain Pattern I, while landslides occur in Rain Patterns II, III and IV. The first landslide of the test with rain pattern II occurred in about $42 \mathrm{~min}$. The first landslide of the test with rainfall pattern III occurred in about $45 \mathrm{~min}$. The first landslide of the test with rainfall pattern IV occurred in about $47 \mathrm{~min}$.

\subsection{Slope instability processes with different soil type}

Figure 7 shows the variation of water content, matrix suction, pore water pressure and total stress of slopes with different soil composition. For the same rainfall intensity, there was no significant difference in the time of volumetric water content starting to rise for different soils. All of them started to increase at about $25 \mathrm{~min}$. However, there were large differences in the final volumetric water content of the different soil types. The upper limit of volumetric water content was the highest for silty soils, at about $36 \%$. The upper limit of volumetric water content for mixed soils is about $30 \%$. Sandy soils have an upper volumetric water content of about $27 \%$. Gravel soils have the lowest upper limit of volumetric water content, which is about $18 \%$. The volumetric water content of silty and mixed soils rises very quickly and reaches its maximum water content at about $35 \mathrm{~min}$. The vol- 
umetric water content of sandy soils rises over a longer period of time and the rate gradually decreases. The volumetric water content of gravel soils plateaued after a small increase.

The initial matrix suction of different soils has great differences. The initial matrix suction of fine-grained soil is higher than that of coarse-grained soil. The initial matrix suction of silty soil is about $78 \mathrm{kPa}$, that of sandy soil is about $52 \mathrm{kPa}$, while that of gravel soil is only about $14 \mathrm{kPa}$, and that of mixed soil is about $48 \mathrm{kPa}$. The changing processes of matrix suction are also different. The matrix suction of silty soil at location I enters the diminish stage from about $28 \mathrm{~min}$, decreases sharply in the time period of $30 \sim 40 \mathrm{~min}$, and finally stabilizes at about $20 \mathrm{kPa}$. The matrix suction of sandy soil and mixed soil decrease at about $25 \mathrm{~min}$, and the matrix suction of sandy soil become stable stage at 35 min with the value of $18 \mathrm{kPa}$. The matrix suction of mixed soil continued to decline and finally decreased to about $8 \mathrm{kPa}$. The matrix suction of gravel soil is very small and does not change significantly in the first 30min of rainfall. It enters into the fluctuating stage from 30min.

Soil type has a strong influence on the changing process of pore water pressure. The increasing process of pore water pressure is longer for mixed soil. The peak occurs between 30 and $40 \mathrm{~min}$ and peaks at about $4 \mathrm{kPa}$. The pore water pressure changes in silty, sandy and gravel soils can be divided into two stages: a rapid increase stage and a stable stage. The increasing stage is about the first $20 \mathrm{~min}$ of the test. When the increasing stage is over, the pore water pressure of the silty soil is greater than that of the sandy soil and that of sandy soil is greater than that of gravel soil.

Different soil types have different total stress values. At Position I, the total stress is highest in the silty soil. It increases slowly during the time period of 10 to $40 \mathrm{~min}$ and remains constant at about $10 \mathrm{kPa}$ during the time period of 40 to $60 \mathrm{~min}$. The total stress of the sandy soil varied little in the first $20 \mathrm{~min}$, increased fluctuating in the time period of 20-50 min, and decreased abruptly at about $50 \mathrm{~min}$ because of the landslide. The total stress of gravel soil is the smallest and increases only slightly during the rainfall, and then stabilizes around $4 \mathrm{kPa}$. The total stress variation pattern of the mixed soil is similar to that of the sandy soil.

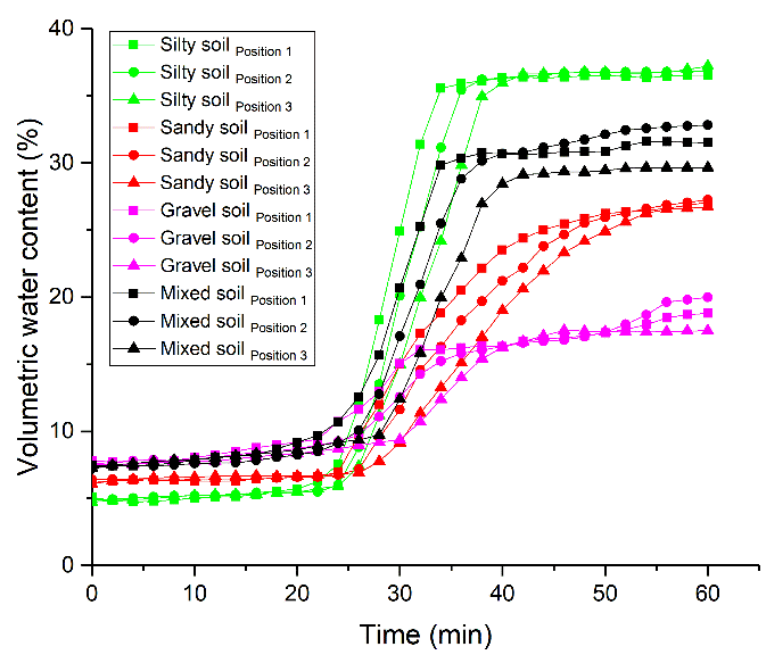

(a)

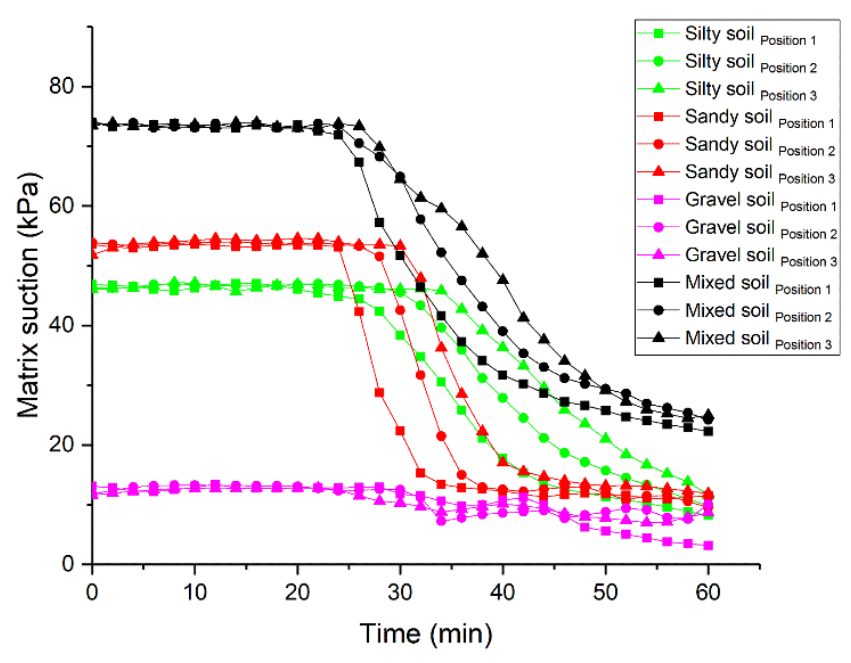

(b) 


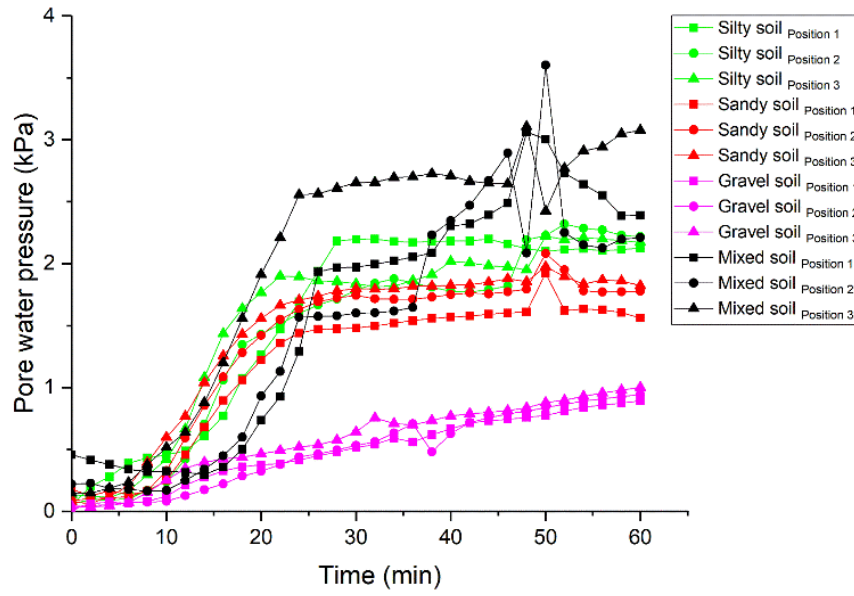

(c)

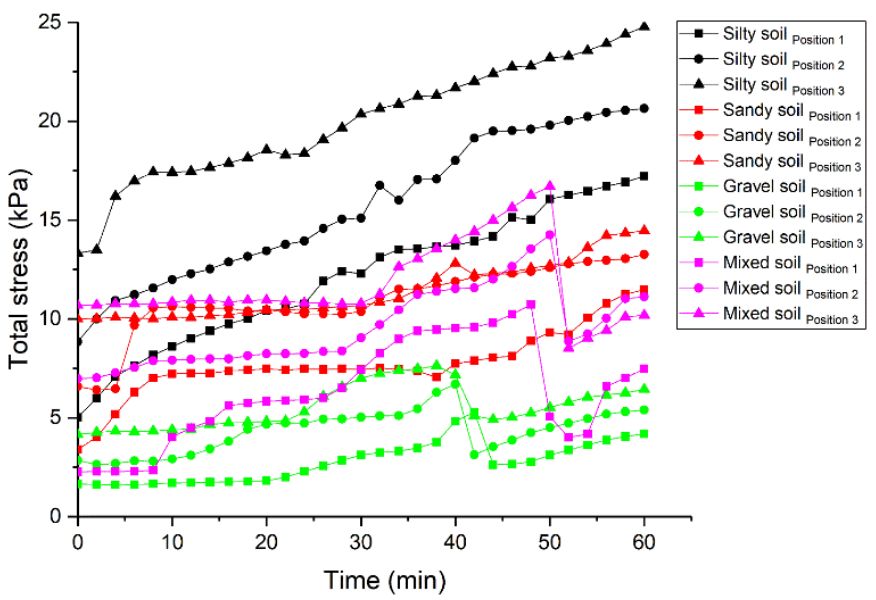

(d)

Figure 7. Variation in measured data when soil types are different: (a) Water content; (b) Matrix suction; (c) Pore water pressure; (d) Total stress.

Soil type is a key factor in determining the stability of slopes. Under the fixed rainfall process and slope conditions set in tests, no landslide occurred when the soil type was silty and sandy. Landslides were generated when the soil type was gravelly and mixed. The initial landslide occurrence time was about $39 \mathrm{~min}$ for gravel soil and about $47 \mathrm{~min}$ for mixed soil.

\subsection{Slope instability processes on different angle slope}

Figure 8 shows the variation process of matrix suction when the slope gradients are different. Different slope gradients have little influence on the variation of volume water content, and the variation of each test is generally similar. The rise speed rate of $30^{\circ}$ slope is less than $5^{\circ}$ slope and $15^{\circ}$ slope.

The changing process of matrix suction of different gradient slopes is generally similar. For example, in test with $30^{\circ}$ slope at position I. In the first $25 \mathrm{~min}$ of rainfall, the change of matrix suction is not obvious. In $26 \sim 46 \mathrm{~min}$, the matrix suction at this location decreases abruptly. As the infiltration of rainfall continues to increase, the soil matrix suction drops to the minimum and stabilizes. Since the precipitation on the steep slope is more converted into surface runoff during the rainfall infiltration process, the infiltration volume is smaller than that of the gentle slope in the same time. The matrix suction starts to decrease earlier for the tests on the gentle slope than those on the steep slope.

The increasing and stable stages of pore water pressure on slopes with different gradients have large differences. Taking location I as an example, when the slope is gentle $\left(5^{\circ}\right)$, the rising curve of pore water pressure resembles a convex function. That is, the function slope is larger at the beginning and the period of $5 \sim 12 \mathrm{~min}$ is the concentrated rising section of pore water pressure. When the slope is $15^{\circ}$, the growth of pore water pressure is approximately linear. When the slope is $30^{\circ}$, the curve of pore water pressure increase is similar to the concave function, which decreases slightly in the time period of $0 \sim 15 \mathrm{~min}$ and increases rapidly in the time period of $20 \sim 25 \mathrm{~min}$. In stable stage, the pore water pressure on the $15^{\circ}$ slope is the largest, around $3.2 \mathrm{kPa}$. The pore water pressure on the $30^{\circ}$ slope is about $2.5 \mathrm{kPa}$, and the pore water pressure on the $5^{\circ}$ slope is stable at about $2.8 \mathrm{kPa}$.

The slope has a significant effect on the changing process of the total stress. For the case of $5^{\circ}$ slope, the total stress at position I, position II increased linearly throughout the test. For the case of $15^{\circ}$ slope, the total stress at position II changes very little in the first 25 min, increases significantly in the time period from 25 to $45 \mathrm{~min}$, and suddenly decreases at about $47 \mathrm{~min}$ due to a landslide. For the case of $30^{\circ}$ slope, the total stress changes little 
in the first $40 \mathrm{~min}$ at position II, increases continuously from $40 \mathrm{~min}$, and decreases suddenly at around 50 min due to landslide.

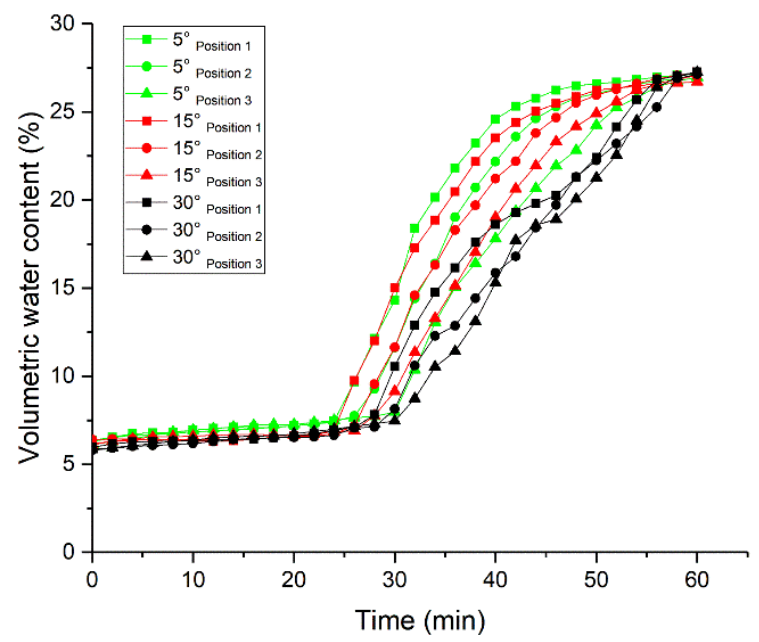

(a)

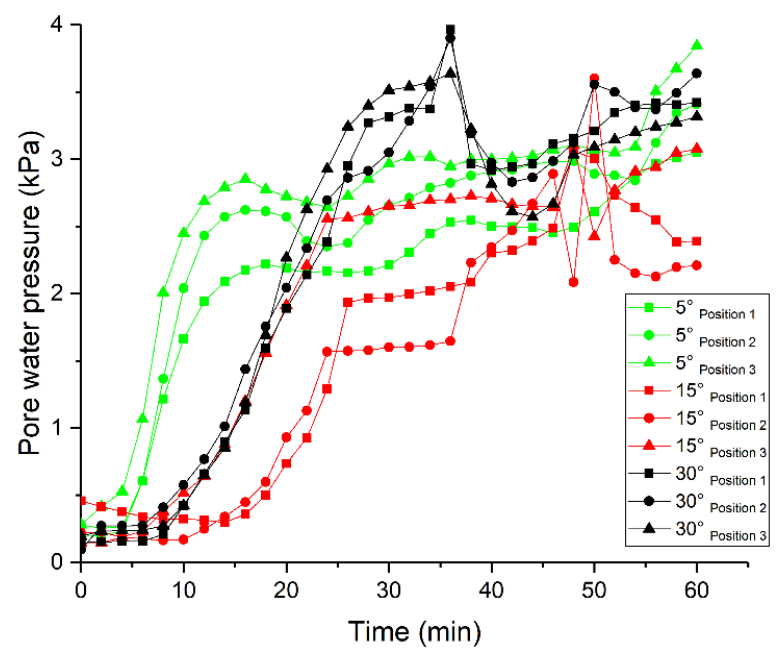

(c)

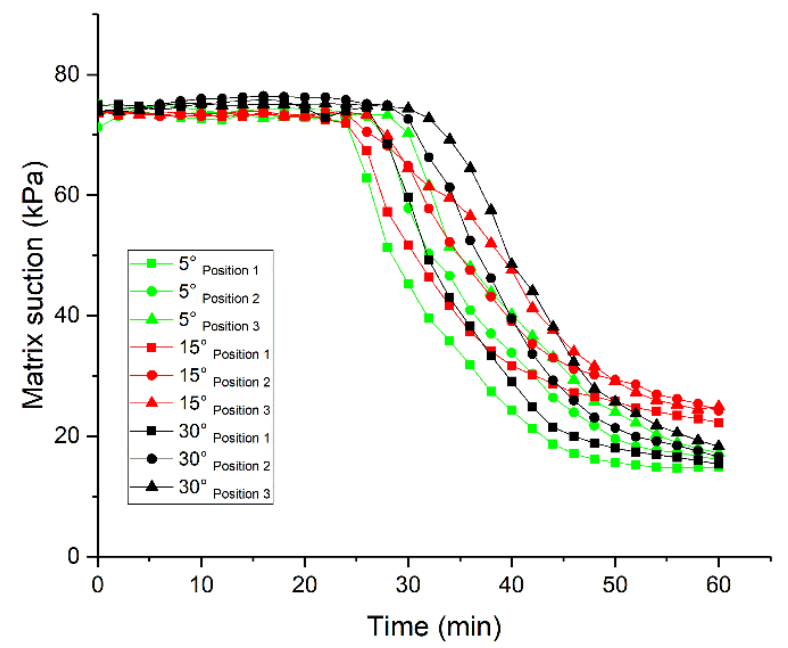

(b)

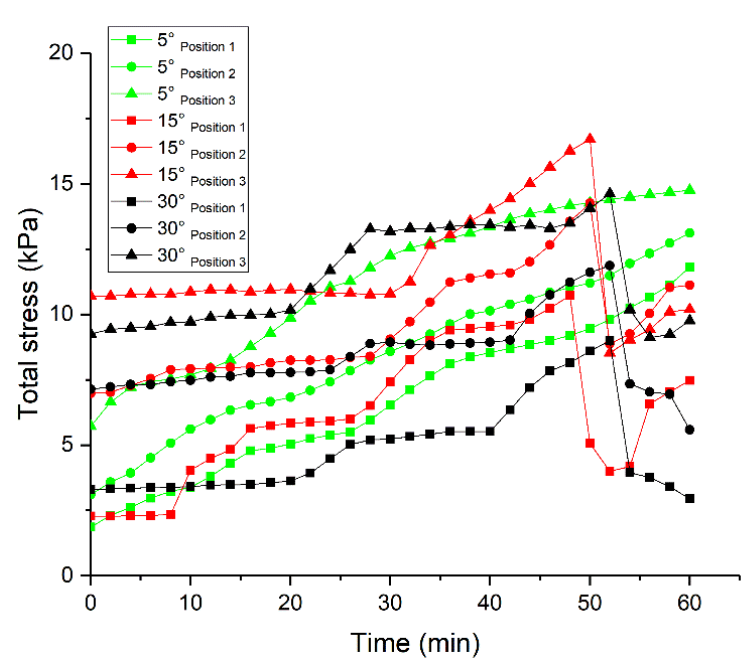

(d)

Figure 8. Variation in measured data when slope gradients are different: (a) Water content; (b) Matrix suction; (c) Pore water pressure; (d) Total stress.

The gradient of the slope is a decisive factor for the occurrence of landslide. No landslide occurs on $5^{\circ}$ slope. Landslide occurs on both $15^{\circ}$ slope and $30^{\circ}$ slope. The initial landslide occurs in about $47 \mathrm{~min}$ on $15^{\circ}$ slope and in about $33 \mathrm{~min}$ on $30^{\circ}$ slope.

\section{Discussion}

Landslides are generated when the stability of the slope soils is reduced by the action of rainfall. The landslide makes part of the soil mass out of its original position and increases sediment yield in the watershed. The sediment yield of landslide for tests with different rainfall intensity, rainfall pattern, slope gradient and soil particle composition is shown in Table 3. All the soil sliding down comes from within $10 \mathrm{~cm}$ of the surface layer of the original mass, so the percentage of the mass of the soil sliding down by landslide to the mass of the upper $10 \mathrm{~cm}$ layer of the original slope mass is used to measure the severity of the landslide.

Table 3. Sediment yield from landslides. 


\begin{tabular}{ccccccc}
\hline $\begin{array}{c}\text { Test } \\
\text { No. }\end{array}$ & Slope $\left(^{\circ}\right)$ & $\begin{array}{c}\text { Rainfall in- } \\
\text { tensity } \\
(\mathbf{m m} / \mathbf{h})\end{array}$ & $\begin{array}{c}\text { Rainfall } \\
\text { pattern }\end{array}$ & Soil sample & $\begin{array}{c}\text { Time of initial land- } \\
\text { slide (min) }\end{array}$ & $\begin{array}{c}\text { Sediment } \\
\text { yield (\%) }\end{array}$ \\
\hline 3 & 15 & 120 & IV & Mixed soil & 47 & 11.20 \\
4 & 15 & 160 & IV & Mixed soil & 40 & 18.20 \\
6 & 15 & 120 & II & Mixed soil & 42 & 14.6 \\
7 & 15 & 120 & III & Mixed soil & 45 & 12.4 \\
10 & 15 & 120 & IV & Gravel soil & 39 & 9.80 \\
12 & 30 & 120 & IV & Mixed soil & 33 & 24.20 \\
\hline
\end{tabular}

The process of soil mass from the initial state to landslides is analyzed according to the changing process of soil water content, matrix suction, pore water pressure and total stress. After the rain acts on the slope soil, the soil water content starts to increase and the matrix suction starts to diminish. The decrease of matrix suction leads to the decrease of soil shear strength, and landslide occurs after the diminish of matrix suction. At the moment before the occurrence of landslide, there is often a brief and sharp rise in pore water pressure. The soil were displaced by landslides, which will lead to a significant reduction of the locally total stress.

The occurrence of landslides and its sediment yield are related to many factors. To investigate the effect of one factor, and the following comparisons keep the other factors same. Under the rainfall intensity of $120 \mathrm{~mm} / \mathrm{h}$ (Test 3), the first landslide occurred at $39 \mathrm{~min}$. Under the rainfall intensity of $160 \mathrm{~mm} / \mathrm{h}$ (Test 4 ), the first landslide occurred at $47 \mathrm{~min}$. It means that the higher the intensity of rainfall, the earlier the initial landslide occurs. The sand yield of Test 4 is also larger than that of Test 3 . When the rainfall intensity is $80 \mathrm{~mm} / \mathrm{h}$, there was no landslide. It indicates that the occurrence of landslide under the test conditions requires the rainfall intensity to exceed $80 \mathrm{~mm} / \mathrm{h}$. The rain pattern also affects the occurrence of landslides and the first landslide occurring time. In the test with rainfall pattern II (Test 6), the first landslide is at $42 \mathrm{~min}$. In the test with rainfall pattern III (Test 7), the first landslide is at $45 \mathrm{~min}$. In the test with rainfall pattern IV (Test 3), the first landslide is at $47 \mathrm{~min}$. In the test with rainfall pattern I, no landslide occurs. For the different soil type, the initial landslide occurrence time of gravel soil is $39 \mathrm{~min}$, and the sediment yield is $9.8 \%$. The initial landslide occurrence time of mixed soil is $47 \mathrm{~min}$, and the sediment yield is $11.2 \%$. No landslide occurred in silty soil and sandy soil. Soils composed of coarse grains are prone to landslide. Landslides occurred on both $15^{\circ}$ slope (Test 3 ) and $30^{\circ}$ slope (Test 12 ). However, the landslide on the $30^{\circ}$ slope occurred earlier, 33 min, than all tests on the $15^{\circ}$ slope. The sediment yield was $24.2 \%$, which was also higher than those with $15^{\circ}$ slopes.

\section{Conclusions}

Landslides is a common type of gravity erosion, which is one of the main reasons for the increase of sediment yield in the watershed. Rainfall is a main factor to induce landslides. In this paper, an artificial rainfall test method is used. Four variables including rainfall intensity, rain type, soil type and slope gradient are set to study. The changing processes of volumetric water content, matrix suction, pore water pressure and total stress during the rainfall are analyzed. The results are as follows:

The changing process of matrix suction consists of initial stage, steep decline stage and stable stage. With the greater intensity of rainfall, the matrix suction will diminish earlier. The pore water pressure continues to rise through the rainfall, and it will start to rise earlier when the rainfall intensity is greater. In the tests with different rainfall patterns, matrix suction began to diminish later when the rainfall intensity peaks in the late stage (pattern II) and the middle stage (pattern III) because the rainfall intensity is less in the initial stage of rainfall. The rate of the increasing curve of the pore water pressure was also slower. When the slope was steeper, the runoff from the surface is stronger, and therefore the infiltrated water will be less. The time at which the soil water content starts to rise and the matrix suction starts to diminish is later than in the cases of gentler slopes. Soil matrix 
suction of different particle composition varies greatly. The process of matrix suction change for soil types containing fine particles (silty, sandy and mixed soil) has three distinct phases: initial, diminishing and stable stage. In contrast, the matrix suction of gravel soils varied less during the rainfall.

The occurrence of landslide is related to the intensity of rainfall intensity and pattern, slope gradient and soil composition. Landslides will be triggered by rainfall of a certain intensity, and according to the results obtained from tests, the rainfall intensity must exceed $40 \mathrm{~mm} / \mathrm{h}$. The higher the rainfall intensity, the earlier the landslide will occur. Rainfall pattern also has influence on landslide generation. For rainfall pattern with gradually decreasing rainfall intensity, if the pore water pressure of the soil has reached the maximum value at the initial stage but no landslide occurs, then no landslide will occur afterwards. If the pore water pressure does not reach the maximum at the initial stage, landslides may occur when the pore water pressure reaches the maximum.

When landslides occur, there is a corresponding significant change in the physical parameters of the slope. The prerequisite for landslide occurrence is that the forces maintaining the interparticle connection of the soil are disrupted, so the landslide occurs after the matrix suction enters the diminish stage. Different soil compositions have sequential landslide occurrence times, with the silty and sandy types occurring earlier than the gravelly and mixed types. The pore water pressure rises briefly before the landslide occurs and falls back after the landslide occurs. Because landslides cause rapid local soil movement, total stress produces rapid changes during landslides and in most cases are obvious decrease.

Sediment yield from landslides is influenced by various factors. When the intensity of rainfall increases, the sediment yield of landslides increases. The sediment yield of landslides with coarser particle composition is greater than that of finer soils. The influence of slope degree on the sediment yield of landslides is most obvious, and the sediment yield of $30^{\circ}$ slope is significantly higher than that of $15^{\circ}$ slope.

Author Contributions: Conceptualization, Y.L. and W.X.; methodology, Y.L. and W.X.; software, Y.L. and Z.D.; validation, Z.D.; investigation, Y.L. and Z.D.; data curation, Y.L. and Z.D..; writingoriginal draft preparation, Y.L.; writing-review and editing, Y.L. and W.X.; funding acquisition, W.X. All authors have read and agreed to the published version of the manuscript.

Funding: This research is supported by the opening fund from State Key Laboratory of Hydraulics and Mountain River Engineering, Sichuan University (Grant No. SKHL1804 and SKHL 2009).

Conflicts of Interest: The authors declare no conflict of interest.

\section{References}

1. Glade, T.; Anderson, M.G.; Crozier, M.J. Landslide hazard and risk; John Wiley \& Sons: 2006.

2. Ray, A.; Bharati, A.K.; Rai, R.; Singh, T.N. Landslide occurrences in Himalayan residual soil: a review. Himal. Geol. 2021, 42, 189-204.

3. Clague, J.J.; Stead, D. Landslides : types, mechanisms and modeling; New York: Cambridge University Press: New York, 2012.

4. $\quad$ Chen, Y. Landslide disaster; Seismological Press: Beijing, 2020.

5. Yi, X.Y.; Feng, W.K.; Bai, H.L.; Shen, H.; Li, H.B. Catastrophic landslide triggered by persistent rainfall in Sichuan, China: August 21, 2020, Zhonghaicun landslide. Landslides 2021, 18, 2907-2921, doi:10.1007/s10346-021-01701-w.

6. Wu, Y.Y.; Zhang, M.; Yang, L.; Liu, T.; Zhang, T.L.; Sun, Q.; Wang, B.; Xie, X.P. Failure mechanisms and dynamics of the Shanzao rockslide in Yongjia County, China on 10 August 2019. Landslides 2021, 18, 2565-2574, doi:10.1007/s10346-021-01673$x$.

7. Xia, M.; Ren, G.M.; Yang, X.L. Mechanism of a catastrophic landslide occurred on May 12, 2019, Qinghai Province, China. Landslides 2021, 18, 707-720, doi:10.1007/s10346-020-01559-4.

8. Dikshit, A.; Sarkar, R.; Pradhan, B.; Segoni, S.; Alamri, A.M. Rainfall Induced Landslide Studies in Indian Himalayan Region: A Critical Review. Appl. Sci.-Basel 2020, 10, doi:10.3390/app10072466.

9. Wang, K.; Zhang, S.J. Rainfall-induced landslides assessment in the Fengjie County, Three-Gorge reservoir area, China. Nat. Hazards 2021, 108, 451-478, doi:10.1007/s11069-021-04691-z.

10. Huang, G.; Zheng, M.X.; Peng, J. Effect of Vegetation Roots on the Threshold of Slope Instability Induced by Rainfall and Runoff. Geofluids 2021, 2021, doi:10.1155/2021/6682113. 
11. Garg, A.; Huang, H.; Kushvaha, V.; Madhushri, P.; Kamchoom, V.; Wani, I.; Koshy, N.; Zhu, H.H. Mechanism of biochar soil pore-gas-water interaction: gas properties of biochar-amended sandy soil at different degrees of compaction using KNN modeling. Acta Geophys. 2020, 68, 207-217, doi:10.1007/s11600-019-00387-y.

Buscarnera, G.; Di Prisco, C. Soil stability and flow slides in unsaturated shallow slopes: can saturation events trigger liquefaction processes? Geotechnique 2013, 63, 801-817, doi:10.1680/geot.11.P.097.

13. Li, W.C.; Dai, F.C.; Wei, Y.Q.; Wang, M.L.; Min, H.; Lee, L.M. Implication of subsurface flow on rainfall-induced landslide: a case study. Landslides 2016, 13, 1109-1123, doi:10.1007/s10346-015-0619-9.

14. Feng, C.X.; Tian, B.; Lu, X.C.; Beer, M.; Broggi, M.; Bi, S.F.; Xiong, B.B.; He, T. Bayesian Updating of Soil-Water Character Curve Parameters Based on the Monitor Data of a Large-Scale Landslide Model Experiment. Appl. Sci.-Basel 2020, 10, doi:10.3390/app10165526.

15. Cui, Y.F.; Zhou, X.J.; Guo, C.X. Experimental study on the moving characteristics of fine grains in wide grading unconsolidated soil under heavy rainfall. J. Mt. Sci. 2017, 14, 417-431, doi:10.1007/s11629-016-4303-x.

16. Wang, G.H.; Sassa, K. Pore-pressure generation and movement of rainfall-induced landslides: effects of grain size and fineparticle content. Eng. Geol. 2003, 69, 109-125, doi:10.1016/s0013-7952(02)00268-5.

17. Chen, N.S.; Zhou, W.; Yang, C.L.; Hu, G.S.; Gao, Y.C.; Han, D. The processes and mechanism of failure and debris flow initiation for gravel soil with different clay content. Geomorphology 2010, 121, 222-230, doi:10.1016/j.geomorph.2010.04.017.

18. Liao, L.P.; Yang, Y.C.; Yang, Z.Q.; Zhu, Y.Y.; Hu, J.; Zou, D.H.S. Mechanical state of gravel soil in mobilization of rainfallinduced landslides in the Wenchuan seismic area, Sichuan province, China. Earth Surf. Dyn. 2018, 6, 637-649, doi:10.5194/esurf-6-637-2018.

19. Huang, K.; Duan, H.P.; Yi, Y.L.; Yu, F.; Chen, S.X.; Dai, Z.J. Laboratory Model Tests on Flow Erosion Failure Mechanism of a Slope Consisting of Anqing Group Clay Gravel Layer. Geofluids 2021, 2021, doi:10.1155/2021/5559052.

20. Pajalic, S.; Peranic, J.; Maksimovic, S.; Ceh, N.; Jagodnik, V.; Arbanas, Z. Monitoring and Data Analysis in Small-Scale Landslide Physical Model. Appl. Sci.-Basel 2021, 11, doi:10.3390/app11115040.

21. Rahardjo, H.; Lee, T.; Leong, E.; Rezaur, R. Response of a residual soil slope to rainfall. Can. Geotech. J. 2005, 42, 340-351, doi:10.1139/t04-101.

Hou, X.K.; Li, T.L.; Qi, S.W.; Guo, S.F.; Li, P.; Xi, Y.; Xing, X.L. Investigation of the cumulative influence of infiltration on the slope stability with a thick unsaturated zone. Bull. Eng. Geol. Environ. 2021, 80, 5467-5480, doi:10.1007/s10064-021-02287-2. Chen, H.; Lee, C.F.; Law, K.T. Causative mechanisms of rainfall-induced fill slope failures. J. Geotech. Geoenviron. Eng. 2004, 130, 593-602, doi:10.1061/(asce)1090-0241(2004)130:6(593).

Cui, P.; Guo, C.X.; Zhou, J.W.; Hao, M.H.; Xu, F.G. The mechanisms behind shallow failures in slopes comprised of landslide deposits. Eng. Geol. 2014, 180, 34-44, doi:10.1016/j.enggeo.2014.04.009.

25. Claessens, L.; Knapen, A.; Kitutu, M.G.; Poesen, J.; Deckers, J.A. Modelling landslide hazard, soil redistribution and sediment yield of landslides on the Ugandan footslopes of Mount Elgon. Geomorphology 2007, 90, 23-35, doi:10.1016/j.geomorph.2007.01.007.

26. Al-Sheriadeh, M.S.; Malkawi, A.I.H.; Al-Hamdan, A.; Abderahman, N.S. Evaluating sediment yield at King Talal Reservoir from landslides along Irbid-Amman Highway. Eng. Geol. 2000, 56, 361-372, doi:10.1016/s0013-7952(99)00119-2.

Koi, T.; Hotta, N.; Ishigaki, I.; Matuzaki, N.; Uchiyama, Y.; Suzuki, M. Prolonged impact of earthquake-induced landslides on sediment yield in a mountain watershed: The Tanzawa region, Japan. Geomorphology 2008, 101, 692-702, doi:10.1016/j.geomorph.2008.03.007.

28. Chuang, S.-C.; Chen, H.; Lin, G.-W.; Lin, C.-W.; Chang, C.-P. Increase in basin sediment yield from landslides in storms following major seismic disturbance. Eng. Geol. 2009, 103, 59-65, doi:10.1016/j.enggeo.2008.08.001.

29. Bovolo, C.I.; Bathurst, J.C. Modelling catchment-scale shallow landslide occurrence and sediment yield as a function of rainfall return period. Hydrol. Process. 2012, 26, 579-596, doi:10.1002/hyp.8158.

30. Bathurst, J.C.; Moretti, G.; El-Hames, A.; Begueria, S.; Garcia-Ruiz, J.M. Modelling the impact of forest loss on shallow landslide sediment yield, Ijuez river catchment, Spanish Pyrenees. Hydrol. Earth Syst. Sci. 2007, 11, 569-583, doi:10.5194/hess11-569-2007.

31. Bathurst, J.C.; Moretti, G.; El-Hames, A.; Moaven-Hashemi, A.; Burton, A. Scenario modelling of basin-scale, shallow landslide sediment yield, Valsassina, Italian Southern Alps. Nat. Hazards Earth Syst. Sci. 2005, 5, 189-202, doi:10.5194/nhess5-189-2005.

32. Burton, A.; Bathurst, J.C. Physically based modelling of shallow landslide sediment yield at a catchment scale. Environ. Geol. 1998, 35, 89-99, doi:10.1007/s002540050296.

33. Yang, S.Y.; Jan, C.D.; Yen, H.; Wang, J.S. Characterization of landslide distribution and sediment yield in the TsengWen River Watershed, Taiwan. Catena 2019, 174, 184-198, doi:10.1016/j.catena.2018.11.011.

34. Gan, F.L.; He, B.H.; Wang, T. Water and soil loss from landslide deposits as a function of gravel content in the Wenchuan earthquake area, China, revealed by artificial rainfall simulations. PLoS One 2018, 13, doi:10.1371/journal.pone.0196657. 